Research Article

\title{
Effectiveness, Safety and Obedience of Dienogest and Leuprolide Acetate in Postlaparoscopic Endometriosis Patients
}

\author{
Efektivitas, Keamanan dan Kepatuhan terhadap Dienoges dan Leuprolide Asetat \\ pada Pasien Endometriosis Pascalaparoskopi
}

\author{
Joko P. Purwanto, Yusuf Effendi, Heriyadi Manan, Theodorus \\ Department of Obstetrics and Gynecology \\ Faculty of Medicine Universitas Sriwijaya \\ Dr. Mohammad Hoesin General Hospital \\ Palembang
}

\begin{abstract}
Objective: Comparing therapeutic effectiveness, safety profile, and adherence between Dienogest and postoperative Leuprolide Acetate in women with endometriosis who underwent laparoscopy.

Methods: This study was a randomized clinical trial comparing the open-label study to compare the effectiveness of therapy, safety profile, and obedience between postoperative dienogest and leuprolide acetate in women with endometriosis who underwent laparoscopy.

Results: From the statistical test it was found that there was the effectiveness of dienogest after 4 weeks of therapy ( $p=$ $0.004)$, after 8 weeks of therapy $(p=0.004)$ and after 12 weeks of therapy ( $p=0.004)$. In the leuprolide acetate group, it was also found that there was the effectiveness of administration after 4 weeks of therapy ( $p=0.004)$, after 8 weeks of therapy $(p=0.004)$ and after 12 weeks of therapy $(p=0.003)$. There was no difference in systolic blood pressure $(p=0.481)$, diastolic blood pressure $(p=1.000)$ and pulse frequency $(p=0.125)$ breath frequency $(p=1.000)$ and temperature $(p=0.236)$ between patients who received dienogest and leuprolide acetate. From the statistical analysis, it was found that there were no differences in side effects in patients who received dienogest and leuprolide acetate $(p=0.238)$.
\end{abstract}

Conclusions: There was no difference in therapeutic effectiveness, and the safety profile assessed by side effects as well as the obedience of postoperative Dienogest and Leuprolide Acetate in endometriosis women undergoing Laparoscopy because in both groups there was a decrease in VAS scores from week to week.

Keywords: endometriosis, dienogest, leuprolide acetate, postlaparoscopy, therapy

\begin{abstract}
Abstrak
Tujuan: Membandingkan efektivitas terapi, profil keamanan, dan kepatuhan antara dienogest dengan leuprolid asetat pascaoperatif pada perempuan endometriosis yang menjalani lapararoskopi.
\end{abstract}

Metode: Penelitian ini merupakan uji klinik acak berpembanding dengan studi label terbuka untuk membandingkan efektivitas terapi, profil keamanan, dan kepatuhan antara dienoges dan leuprolid asetat pascaoperatif pada perempuan endometriosis yang menjalani lapararoskopi.

Hasil: Dari uji statistik didapatkan hasil terdapat efektivitas pemberian dienoges setelah 4 minggu terapi $(p=0,004)$, setelah 8 minggu terapi $(p=0,004)$, dan setelah 12 minggu terapi $(p=0,004)$. Pada kelompok leuprolid asetat juga didapatkan hasil terdapat efektivitas pemberian setelah 4 minggu terapi ( $p=0,004)$, setelah 8 minggu terapi ( $p$ $=0,004)$ dan setelah 12 minggu terapi $(p=0,003)$. Tidak terdapat perbedaan tekanan darah sistolik $(p=0,481)$, tekanan darahdiastolik $(p=1,000)$ dan frekuensi nadi ( $p$ $=0,125)$ frekuensi napas $(p=1,000)$ dan suhu $(p=0,236)$ antara pasien yang mendapatkan dienoges dan leuprolid asetat. Dari analisis statistik didapatkan hasil tidak terdapat perbedaan efek samping pada pasien yang mendapatkan dienoges dan leuprolid asetat $(p=0,238)$.

Kesimpulan: Tidak terdapat perbedaan efektivitas terapi, dan profil keamanan yang dinilai dari efek samping serta kepatuhan dienoges dan leuprolid asetat pascaoperatif pada perempuan endometriosis yang menjalani Lapararoskopi karena pada kedua kelompok terdapat penurunan VAS skor dari minggu ke minggu.

Kata kunci: endometriosis, dienoges, leuprolide acetate, postlaparoscopy, terapi 


\section{INTRODUCTION}

Endometriosis is a gynecological disorder characterized by the presence of endometrial like tissue located outside the uterus or endometrial cavity. ${ }^{1-3}$ When symptomatic, endometriosis can cause chronic pain, dysmenorrhea, dyspareunia, non-cyclic pelvic pain, infertility, and bleeding disorders. ${ }^{4}$ The multicentre study reported that health care costs related to endometriosis included surgery costs $(29 \%)$, monitoring costs (19\%), hospital care costs (18\%), and doctor consultation fees (16\%). This high cost is related to the severity of endometriosis, pelvic pain, infertility, and the duration of symptoms before the diagnosis. ${ }^{2}$ Surgical therapy is the best and effective approach to eradicate disease and relieve symptoms of endometriosis. However, the data show a high level of postoperative recurrence and complications related to surgical therapy. ${ }^{4-9}$ The use of estrogen-lowering medical therapy after short-term surgery is recommended to improve the efficacy of therapy, one of which is dienogest. Dienogest, has fewer side effects in clinical use, has now been used as endometriosis therapy in Germany, France and Japan. ${ }^{10}$ DNG clinical trials for 12 and 24 weeks provide information about optimum dosages and useful characteristics and safety as long-term management of endometriosis. Oral $2 \mathrm{mg}$ daily DNG therapy for more than 90 weeks caused regression of endometrioma and good symptom elimination. ${ }^{11}$ However, comparison of effectiveness, safety profile, and obedience of treatment between dienogest and $\mathrm{Gn}-\mathrm{RH}$ analogue, such as leuprolide acetate have not been studied much go on. Therefore, further research is needed regarding this matter.

\section{METHODS}

This study was a randomized clinical trial comparing the open-label study to compare the effectiveness of therapy, safety profile, and obedience between postoperative dienogest and leuprolide acetate in women with endometriosis who underwent laparoscopy. This research was carried out in the Department of Midwifery and Gynecology at the RSMH / Faculty of Medicine Universitas Sriwijaya, Palembang. The study period starts from 01 July 2018 to 28 February 2019 with the sampling time starting from 01 July 2018 to 30 November 2018. The study sample was women of reproductive age with postlaparoscopic endometriosis and fulfilling the study inclusion criteria. The inclusion criteria in this study were women of reproductive age who had undergone laparoscopy and were diagnosed as endometriosis cysts and were classified according to revised ASRM criteria with pain complaints (VAS> 3) after the first menstruation.

Exclusion criteria in this study were pregnant, lactating or amenorrhoea patients in 3 months of screening, patients who had a history of endometriosis surgical or medical therapy (such as the use of $\mathrm{GnRH}$ agonists, danazol progestins, and oral contraceptives), experienced liver, endocrine, and neoplastic disorders. abnormal gynaecological examination and abnormal cervical cytology smear.

\section{Work Procedures}

Identify sufferers including name, age, gender, address, diagnosis, education, work and income. Special history; obstetric and gynecological history (parity, the first day of last menstruation), previous history (history of chronic intestinal infectious diseases, history of gastrointestinal tract surgery, history of chronic kidney disease, history of neurological diseases and history of chronic liver disease). Physical examination included an examination of general conditions, blood pressure, pulse, breath, temperature, height. Determination of nutritional status carried out by measuring pre-treatment weight and height, 4th week, 8th week and 12th week (measurement of body weight, weighing was carried out by researchers assisted by paramedics on the subject using the SIMC stand scale plus a ZT-120 height gauge, with an accuracy of 100 grams, height measurement).

Measurements were made by researchers assisted by paramedics, in a standing position using the SIMC stand scale plus a ZT-120 height gauge. Participants in previous studies are given an explanation of the research that will be conducted. Those who agreed to participate in this study were asked to sign a letter of agreement that had been provided for the study. Then for all patients who will be included in this study. Determination of endometriosis stage is done through diagnostic laparoscopy based on endometriosis scoring of the American Society of Reproductive Medicine (ASRM). This stage is divided into four categories of severity. Patients were randomized to a ratio of 1: 1 to get oral dienogest at a daily dose of 
$2 \mathrm{mg}$ at the same time every day and injection of depot leuprolide acetate ( $\mathrm{Gn}-\mathrm{RH}$ analogue) intramuscularly every 4 weeks for 12 weeks (three injections). Randomization was carried out during postoperative control (7 days postoperatively) after definitive histopathological diagnosis of endometriosis was available. Dienogest therapy is given on the first day after the onset of the first postoperative menstrual cycle, whereas leuprolide acetate injection begins within the first three days of the first postoperative menstrual cycle. Both therapies are given for 12 weeks. Effectiveness of therapy assessed by assessing changes in pain at week 4, week 8, and week 12 which were assessed through changes in VAS assessment.

Safety profile is a safety profile that is assessed based on reports of side effects reported by patients and physical examination results (blood pressure and weight measurement). These side effects were assessed as pre-treatment, week 4, week 8 , week 12 . Obedience is to assess patient compliance is undergoing therapy which is assessed through a questionnaire (for Dienogest) and the accuracy of the date of re-control (for Dienogest and Leuprolide acetate).

\section{RESULTS}

Randomized clinical trials comparing the openlabel study to compare therapeutic effectiveness,

Table 1. Baseline Data for Research Subjects

\begin{tabular}{|c|c|c|c|}
\hline \multirow[t]{2}{*}{ Variable } & \multicolumn{2}{|c|}{ Group } & \multirow[t]{2}{*}{ P-value* } \\
\hline & Dienogest & Leuprolide acetate & \\
\hline \multicolumn{4}{|l|}{ Age } \\
\hline $20-35$ & $7(70.0)$ & $8(80.0)$ & $1.000^{\mathrm{a}}$ \\
\hline$>35$ & $3(30.0)$ & $2(20.0)$ & \\
\hline \multicolumn{4}{|l|}{ Education } \\
\hline Average & $6(60.0)$ & $6(60.0)$ & $1.000^{\mathrm{a}}$ \\
\hline High & $4(40.0)$ & $4(40.0)$ & \\
\hline \multicolumn{4}{|l|}{ Parity } \\
\hline 0 & $7(70.0)$ & $9(90.0)$ & $0.582^{a}$ \\
\hline $1-2$ & $3(30.0)$ & $1(10.0)$ & \\
\hline \multicolumn{4}{|l|}{ Body Mass Index } \\
\hline Normal & $3(30.0)$ & $6(60.0)$ & $0.343^{b}$ \\
\hline Overweight & $3(30.0)$ & $1(10.0)$ & \\
\hline Obese & $4(40.0)$ & $3(30.0)$ & \\
\hline \multicolumn{4}{|l|}{ Vas Score } \\
\hline Mean \pm SD & $4.90 \pm 0.88$ & $4.60 \pm 0.84$ & $0.411^{c}$ \\
\hline Median (Min-Max) & $5(4-6)$ & $4(4-6)$ & \\
\hline \multicolumn{4}{|c|}{ Systolic Blood Pressure } \\
\hline Mean \pm SD & $113.0 \pm 4.83$ & $113.0 \pm 6.75$ & $0.895^{c}$ \\
\hline Median (Min-Max) & $110(110-120)$ & $110(100-120)$ & \\
\hline \multicolumn{4}{|c|}{ Diastolic Blood Pressure } \\
\hline Mean \pm SD & $71.0 \pm 3.16$ & $75.0 \pm 5.27$ & $0.057^{c}$ \\
\hline Median (Min-Max) & $70(70-80)$ & $75(70-80)$ & \\
\hline
\end{tabular}

safety profile, and obedience between postoperative dienogest and leuprolide acetate in women with endometriosis who underwent laparoscopy have been conducted at the Fertility and Endocrinology Clinic Department of Obstetrics and Gynecology in RSMH / Medical Faculty of UNSRI Palembang. The research samples that fulfilled the inclusion and exclusion criteria were 20 people, 10 people received dienogest and 10 others received leuprolide acetate.

\section{General Characteristics of Research Subjects}

The general characteristics of the research subjects are shown in table 1. Based on age, the average age of endometriosis patients was 33.3 \pm 6.23 years with an age range of 25-46 years, patients aged $20-35$ years were 15 people (75\%) and patients with age $>35$ years as many as 5 people (25\%). Both the dienogest and leuprolide acetate groups obtained the majority of patients aged 20-35 years. The statistical test showed that there was no age difference between patients who received dienogest and leuprolide acetate $(p=1.000)$. Based on education, it was found that the majority of patients had secondary education in both the dienogest and leuprolide acetate groups. Based on the statistical test, the results showed no difference in education between patients who received dienogest and leuprolide acetate $(p=1.000)$. 


\section{Pulse Frequency}

Mean \pm SD

Median (Min-Max)

Breath Frequency

Mean \pm SD

Median (Min-Max)

Temperature

Mean \pm SD

Median (Min-Max)

$\begin{array}{ccc}82.2 \pm 5.99 & 82.7 \pm 5.21 & 0.433^{c} \\ 84(68-92) & 80(77-92) & \\ 20.8 \pm 1.03 & 19.6 \pm 1.26 & 0.038^{c} \\ 20(20-22) & 20(18-22) & \\ 36.9 \pm 0.16 & 36.7 \pm 0.29 & 0.137^{c} \\ 36.8(36.8-37.3) & 36.8(36.2-37.2) & \end{array}$

${ }^{a}$ Fisher Exact Test, $p=0.05,{ }^{b}$ Pearson Chi Square, $p=0.05,{ }^{c}$ Mann-Whitney test, $p=0.05$

The majority of endometriosis patients do not have children (80\%), both in the dienogest and leuprolide acetate groups, the majority of patients do not have children. With the statistical test, it was found that there was no difference in parity between patients who received dienogest and leuprolide acetate $(p=0.582)$. The Body Mass Index (BMI) in this study was divided into normal, overweight and obese. In the dienogest group, 3 patients (30\%) had normal BMI, 3 patients (30\%) overweight and 4 patients (40\%) obese, while in the leuprolide acetate group, 6 patients (60\%) had normal BMI, 1 patient (10\%) overweight and 3 patients (30\%) obese. Based on the statistical test, the results showed that there was no difference in body mass index between patients who received dienogest and leuprolide acetate $(p=0.343)$. This study also found no difference in VAS scores ( $p=0.411)$, systolic blood pressure $(p=0.895)$, diastolic blood pressure $(p=0.057)$, pulse frequency $(p=0.433)$ and temperature $(p=$ 0.137 ) between patients who received dienogest and leuprolide acetate, but found differences in respiratory frequency before intervention between patients who received dienogest and leuprolide acetate $(p=0.037)$.

\section{Comparison of the Effectiveness of Dienogest and Leuprolide Acetate VAS Score}

On figure 1, it can be seen that there is a decrease in VAS scores from week to week in both the dienogest and leuprolide acetate groups. With statistical analysis, it was found that there was effectiveness in the administration of dienogest after 4 weeks of therapy $(p=0.004)$, after 8 weeks of therapy ( $p=0.004)$ and after 12 weeks of therapy ( $p=0.004)$. In the leuprolide acetate group, it was also found that there was the effectiveness of administration after 4 weeks of therapy $(p=0.004)$, after 8 weeks of therapy $(p=$ $0.004)$ and after 12 weeks of therapy ( $p=0.003)$. Besides, it was found that there was no difference in VAS scores after 4 weeks of therapy $(p=0.476)$, after 8 weeks of therapy $(p=0.810)$ and after 12 weeks of therapy $(p=1,000)$ between patients who received dienogest and leuprolide acetate.

Tabel 2. Comparison of the effectiveness of therapy in the Dienogest group with Leuprolide Acetate after 4, 8 and 12 weeks of treatment

\begin{tabular}{lccccccc}
\hline \multicolumn{1}{c}{ Variable } & \multicolumn{3}{c}{ Dienogest } & \multicolumn{3}{c}{ Leuprolid acetat } \\
\hline & before & after & P-value* & before & after & P-value* $^{*}$ P-value* $^{*}$ \\
VAS Weeks-4 & $4.9 \pm 0.88$ & $2.4 \pm 1.26$ & 0.004 & $4.6 \pm 0.84$ & $2.7 \pm 0.82$ & 0.004 & 0.476 \\
VAS Weeks-8 & $4.9 \pm 0.88$ & $1.0 \pm 1.33$ & 0.004 & $4.6 \pm 0.84$ & $0.9 \pm 0.74$ & 0.004 & 0.810 \\
VAS Weeks-12 & $4.9 \pm 0.88$ & $0.2 \pm 0.42$ & 0.004 & $4.6 \pm 0.84$ & $0.2 \pm 0.42$ & 0.003 & 1.000 \\
\hline
\end{tabular}

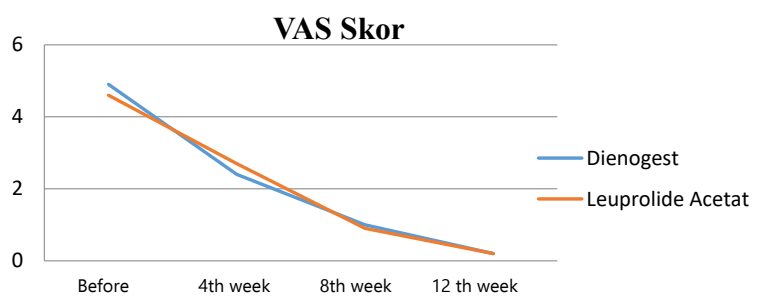

Figure 1. Comparison of VAS Score after Therapy
Hemodynamic Parameters (Systolic Blood Pressure, Diastolic Blood Pressure, Pulse Frequency, Breath Frequency and Temperature)

In this study it was found that there was no difference in systolic blood pressure $(p=0.157)$, diastolic blood pressure $(p=0.059)$ and pulse frequency ( $p=0.196$ ) dienogest group, but differences in respiratory frequency $(p=0.046)$ 
and temperature $(p=0.007)$ in the dienogest group, whereas in the leuprolid acetate group it was found that there was no difference in diastolic blood pressure ( $p=0.564)$ and pulse frequency $(p=0.609)$ breath frequency $(p=0.609)$ and temperature ( $p=0.202$ ) but found differences systolic blood pressure ( $p=0.046)$. In addition, it was found that there was no difference in systolic blood pressure ( $p=0.481)$, diastolic blood pressure ( $p=1.000$ ) and pulse frequency $(p=0.125)$ breath frequency $(p=1,000)$ and temperature $(p=0.236)$ between patients who get dienogest and leuprolide acetate.

Comparison of Safety Profiles Based on Amount and Proportion of Side Effects Reported Regarding Therapy in Dienogest Groups with Leuprolide Acetate

\section{Fourth Week Therapy}

No side effects after 4 weeks of therapy were found in either patient who received dienogest or leuprolide acetate.

\section{Eighth Week Therapy}

Side effects found after 8 weeks of therapy in this study were 8 out of 20 patients (40\%) including joint pain, vaginal dryness, headaches and hot flushes. Side effects of joint pain and hot flushes were found in both groups but side effects of vaginal dryness were only found in the leuprolide acetate group and headache side effects were only found in the dienogest group. With statistical analysis, it was found that there were no differences in the 8-week side effects between patients who received dienogest and leuprolide acetate $(p=0.504)$.

\section{Twelfth Week Therapy}

Side effects found after 12 weeks of therapy in this study were 14 out of 20 patients (70\%) including joint pain, vaginal dryness, vaginal dryness with decreased libido, headaches, migraines and hot flushes. Side effects of vaginal dryness with decreased libido and hot flushes were found in both groups but side effects of vaginal dryness and migraine were only found in the leuprolide acetate group and side effects of joint pain and headache were only found in the dienogest group. With statistical analysis, it was found that there were no differences in the 12th-week side effects between patients who received dienogest and leuprolide acetate $(p=0.238)$.

\section{Comparison of Compliance Profile between Dienogest and Leuprolide Acetate Groups}

In the study, endometriosis patients had moderate and high adherence to drug consumption. With statistical analysis, there was no difference in the 8th-week compliance $(p=0.211)$ and 12th $(p=$ 0.474 ) between patients who received dienogest and leuprolide acetate, only at week 4 there were differences in adherence between patients who received dienogest and leuprolide acetate $(p=$ 0.033).

Table 3. Comparison of Compliance Profiles between Dienogest and Leuprolide Acetate Groups

\begin{tabular}{|c|c|c|c|}
\hline \multirow[t]{2}{*}{ Variable } & \multicolumn{2}{|c|}{ Group } & \multirow[t]{2}{*}{ P-value* } \\
\hline & Dienogest & Leuprolide acetate & \\
\hline \multicolumn{4}{|l|}{$4^{\text {th }}$ Week Compliance, } \\
\hline HighCompliance & $5(50)$ & $10(100)$ & 0,033 \\
\hline AverageCompliance & $5(50)$ & $0(0)$ & \\
\hline \multicolumn{4}{|l|}{$8^{\text {th }}$ Week Compliance } \\
\hline High Compliance & $7(70)$ & $10(100)$ & 0,211 \\
\hline Average Compliance & $3(30)$ & $0(0)$ & \\
\hline \multicolumn{4}{|l|}{$12^{\text {th }}$ Week Compliance } \\
\hline HighCompliance & $8(80)$ & $10(100)$ & 0,474 \\
\hline AverageCompliance & $2(20)$ & $0(0)$ & \\
\hline
\end{tabular}

Fisher Exact Test, $\mathrm{p}=0.05$ 


\section{DISCUSSION}

Endometriosis is a disorder characterized by the growth of stromal tissue and ectopic endometrial glands (outside the uterus), which can cause dysmenorrhoea, dyspareunia, non-cyclic pelvic pain, and subfertility. ${ }^{8,12}$ The peak incidence of endometriosis at the age of 40 years. ${ }^{8}$ Endometriosis generally occurs in the reproductive age of 2529 years, but can also occur during puberty and post-menopausal women who receive hormone replacement therapy. ${ }^{13}$

In this study, the average age of endometriosis patients was $33.3 \pm 6.23$ years with an age range of 25-46 years, the majority of endometriosis patients in this study were between the ages of 20-35 years (75\%). The results of the study were not much different but slightly larger compared to the study. In 2014 where the average age of endometriosis patients was $31.1 \pm 10.4$ with a range of 17- 53 years. Likewise with the research conducted. In 2017 which showed the results of the age of endometriosis patients were slightly larger compared to this study, which amounted to $35.8 \pm 4.1$ years.

In this study the majority of endometriosis patients had secondary education (60\%), this result is in line with the study. In 2014 which received the majority of endometriosis patient education was secondary education of $54.3 \%$. The majority of endometriosis patients in this study did not have children (80\%), this is in line with the research. In 2017 which showed results as much as $42 \%$ of endometriosis patients did not have children. In 2006 which showed the results of the majority of endometriosis patients not having children (70.7\%).

In addition, a study in 2014 found that as many as $62.9 \%$ of endometriosis patients did not have children. Nuliparitas is closely related to endometriosis. The prevalence of endometriosis in nulligravida, nulliparous, and with a history of abortion was quite high. ${ }^{12}$

Low body mass index and high consumption of caffeine or alcohol increase the risk of endometriosis. ${ }^{14}$ In this study, $45 \%$ of endometriosis patients had normal BMI. In line with the results of this study, in 2006 it was found that the majority of endometriosis patients had normal BMI. In
2017 showed a mean BMI of endometriosis patients of approximately $23.3 \mathrm{~kg} / \mathrm{m} 2$ where the average was in the category of normal BMI.

In this study, the sample was divided into two groups, namely the group receiving dienogest therapy and one group received leuprolide acetate therapy. In addition to age, education, parity and body mass index, at the beginning of the study VAS examination scores and hemodynamic characteristics included systolic blood pressure, diastolic, pulse frequency, breathing frequency and temperature. Using statistical analysis it was found that there were no differences in the initial data in both groups, general characteristics, hemodynamic characteristics and VAS scores so that the two groups were worthy of comparison.

\section{Effectiveness of Dienogest and Leuprolide Acetate on score VAS}

In this study, the degree of pain was determined by using the Visual Analogue Score (VAS), which is a $10 \mathrm{~cm}$ scale that at the left end is written as painless $(0)$ and at the right end is very painful (10). The use of VAS scale is easier, more efficient and easier for patients to understand compared to other scales. VAS also methodologically has better quality, where it is also easy to use, only uses a few words so the vocabulary does not become a problem. William et al also conducted a literature review on three pain measuring scales and concluded that VAS was statistically the strongest because it could present data in form ratio. In this study, VAS scores were examined before and after administration of dienogest therapy and leuprolide acetate therapy.

Dienogest (DNG) is a selective progesterone receptor agonist that has been shown to reduce endometriosis lesions through several biological mechanisms. Dienogest proved to be more effective than placebo in reducing pain (assessed by visual analogue scale (VAS) scores or combinations, such as VAS scores and consumption of analgesics (ibuprofen) in women with endometriosis with a pelvic pain score of 30 or more on a scale of $0-100(0=$ no pain up to $100=$ unbearable pain) ${ }^{8}$

In this study it was found that there was a decrease in VAS scores from week to week after administration of dienogest, this showed 
that dienogest was effective in reducing pain in patients with endometriosis after ingestion of 4, 8 and 12 weeks of therapy. In 2016 showed the results of dienogest therapy proved to reduce the incidence of dyspareunia $(p<0.05)$, dysmenorrhoea $(p<0.05)$, premenstrual pain ( $p<0.05)$, diffuse pelvic pain or pain during examination. Dienogest group $2 \mathrm{mg}$ and dienogest $4 \mathrm{mg}$ had less dyspareunia and dysmenorrhea (6.9\% and $5.7 \%$ respectively) than pretreatment $(51.7 \%$ and $57.1 \%){ }^{4}$

Leuprolide acetate is a synthetic nonapeptide $\mathrm{GnRH}$ analogue. This drug inhibits synthesis of luteinizing hormone (LH) and Follicle Stimulating Hormone (FSH) through a negative feedback mechanism which further decreases the production of estrogen and androgens. Although it is not able to effectively eliminate endometrial tissue, leuprolide acetate is effective in managing symptoms and decreasing the size of the lesion. Within 3 months of therapy, leuprolide acetate has been proven to be safe and has a positive effect to eliminate dysmenorrhoea and pelvic pain.

In this study there was a reduction in VAS scores from week to week after administration of leuprolide acetate, suggesting that leuprolide acetate was effective in reducing pain in patients with endometriosis after ingestion of 4,8 and 12 weeks of therapy. Clinical trials comparing leuprolide acetate and danazol $800 \mathrm{mg} \mathrm{/} \mathrm{day} \mathrm{concluded} \mathrm{that} \mathrm{leuprolide} \mathrm{has}$ the same effectiveness as danazol in reducing clinical symptoms and decreasing the size of endometriosis lesions. Recent studies and clinical trials report that the addition of hormone replacement therapy (estradiol/progesterone) to patients treated with leuprolide acetate minimizes the negative effects of this drug on bone and prolongs the pain-free duration ${ }^{1}$

After comparison, there were no differences in VAS scores after 4, 8 or 12 weeks of therapy between patients who received dienogest and leuprolide acetate. This shows that the dienogest is as effective as leuprolide acetate in reducing pain in endometriosis patients.
In the hemodynamic characteristics, it was found that there was a significant decrease in temperature and frequency of breath in the group given dienogest but did not show a significant difference after being compared with the leuprolide acetate group. This shows that dienogest and leuprolide have the same hemodynamic effects in endometriosis patients.

Increased temperature can reflect an increased inflammatory response with pyrogenic activity against the phenomenon of retrograde menstruation in patients with endometriosis. Recent investigations have focused on the inflammatory response proportional to evaluating serum and Peritoneal Fluid (PF) for each component of the response, including those related to autoimmunity, peritoneal macrophage function, and prostaglandin (PG). It is hypothesized that the inflammatory response caused by endometriosis results in an increase in the number, concentration, and activation of the pelvic macrophages. This, in turn, causes the release of endogenous pyrogens.

For the safety profile, there is no difference in the side effects of using dienogest and leuprolide acetate. Side effects that occur include joint pain, vaginal dryness, vaginal dryness with decreased libido, headaches, migraines and hot flushes. Side effects of vaginal dryness with decreased libido and hot flushes were found in both groups but side effects of vaginal dryness and migraine were only found in the leuprolide acetate group and side effects of joint pain and headache were only found in the dienogest group.

In this study, we can conclude that there is no difference in therapeutic effectiveness, safety profile, and obedience between Dienogest and postoperative Leuprolide Acetate in endometriosis women undergoing Laparoscopy, which means the null hypothesis is accepted. 


\section{REFERENCES}

1. Wilson AC, Meethal SV, Bowen RL, Atwood CS. Leuprolide acetate: a drug of diverse clinical applications. Expert Opin Invest Drugs. 2007; 16(11):1-13.

2. deMarqui ABT. Evaluation of endometriosis-associated pain and the influence of conventional treatment: a systematic review. Rev Assoc Med Bras. 2015; 61(6):50718.

3. Lee DY, Park HG, Yoon BK, Choi DS. Effects of different add-back regimens on hypoestrogenic problems by postoperative gonadotropin-releasing hormone agonist treatment in endometriosis. Obstet Gynecol Sci. 2016;59(1):32-8.

4. Angioni S, Cofelice V, Pontis A, Tinelli R, Socolov R. New trends of progestins treatment of endometriosis. Gynecol Endocrinol. 2014; 30(11): 769-73.

5. Busacca M, Somigliana E, Bianchi A, Marinis SD, Calia C et al. Post-operative Gn-RH analogue treatment after conservative surgery for symptomatic endometriosis stage III-IV: a randomized controlled trial. Hum Reprod. 2001; 16(11): 2399-2402.

6. Zito G, Luppi S, Giolo E, Martinelli M, Venturin I et al. Medical Treatments for Endometriosis-Associated Pelvic Pain. Bio Med Research Int. 2014; 1: 1-12.

7. Schindler AE. Dienogest in long-term treatment of endometriosis. Int J Women's Health 2011:3 175-84.
8. Ferrero $\mathrm{S}$, Remorgida $\mathrm{V}$, Venturini $\mathrm{PL}$, Bizzarri $\mathrm{N}$. Endometriosis: the effects of dienogest. Clin Evidence 2015; 6:1-8.

9. Tsai HW, Wang PH, Huang BS, Twu NF, Yen MS, et al. Low-dose add-back therapy during postoperative GnRH agonist treatment. Tai J Obstet Gynecol. 2016; 5(5): 55-9.

10. Katsuki Y, Takano Y, Futamura Y, Shibutani Y, Aoki D. Effects of dienogest, a synthetic steroid, on experimental endometriosis in rats. Eur J Endocrinol. 1998; 138: 21626.

11. Riviello C, Cozzolino M, Pavone D. Regression of a Large Endometrioma after Treatment with Dienogest. JFIV Reprod Med Genet. 2016; 4: 168-9.

12. Bellelis P, Dias JR, Podgaec S, Gonzales M, Baracat EC et al. Epidemiological and clinical aspects of pelvic endometriosis-a case series. Rev Assoc Med Bras. 2010; 56(4): 467-71.

13. The American College of Obstetricians and Gynecologists. Management of Endometriosis. Obstet Gynecol Bull. 2010; 116 (1): 223-36.

14. Ek $M$, Roth $B$, Ekström $P$, Valentin $L$, Bengtsson $M$ et al. Gastrointestinal symptoms among endometriosis patients-A case-cohort study. BMC Women's Health. 2015; 15(59): 1-10. 